\title{
CONTEMPORARY DEVELOPMENTS IN BRITISH PRESERVATION LAW AND PRACTICE
}

\author{
GrathaM Ashworth*
}

In the span of approximately five years, there has been a phenomenal change in British attitude towards historic buildings. This is illustrated by comparing two authorities writing only three and a half years apart. An editorial written in early I967, referring to one particular locality in which the number of listed buildings was reduced in less than twenty years from 130 to twenty-five, noted:

What has happened here is not unique. It has happened all over Britain. The I947 Act, which was intended to give a measure of protection to such pleasant corners of our towns, has failed to do so. In a mere twenty years irreparable harm has been done to character, dignity and urban values built up over the centuries. Unless the double process of conservation and renewal is brought quickly under control, we shall, within the foreseeable future, have damaged our heritage beyond repair. ${ }^{1}$

By mid-r97o the situation had changed so much that the Preservation Policy Group, a body with members from various branches of government, could write, "we have no major recommendations to make about legislation . ..."2 While there are some who have reservations about the final adequacy of the detail of the legislation, there is general agreement with the view of the Policy Group.

\section{I}

\section{The Statutory Scheme in ig66}

There is a difference in British law between a listed building and a scheduled ancient monument. A listed building is one which has been listed by the Secretary of State for the Environment as being of special architectural or historic interest. Normally, these are inhabited buildings. Ancient monuments are buildings or other structures, such as mounds, walls, and, interestingly, caves, which have been scheduled under the Ancient Monuments Act and which are the responsibility of the Minister of Public Buildings and Works, ${ }^{3}$ now also within the Department of the Environment. They are usually unoccupied.

The situation with regard to ancient monuments is today substantially the same as it was in the first half of this century. Ancient monuments include "any building, structure or other work ... of which the preservation is, in the opinion of

\footnotetext{
*M.C.D., B.Arch., A.R.I.B.A., F.R.T.PI.; Director, Civic Trust for the North West, Manchester, England.

'THE ARCHTtEcts' JoURNAI, Jan. I967.

${ }^{2}$ Preservation Policy Group, Report to Minister of Housing and Local Gov't i25 (May x970).

${ }^{8}$ Ancient Monuments Consolidation and Amendment Act r9r3, $3 \& 4$ Geo. 5, c. $32, \S \mathrm{I}$.
} 
the ... [Minister], a matter of public interest by reason of the historic, architectural, traditional, artistic or archaeological interest attaching thereto." The Minister of Works was given power to acquire or accept the ownership or guardianship of these monuments, to use national funds for their upkeep, and to receive voluntary contributions towards them. Similar powers are given to local authorities. He has power to intervene when a building which he considers to be an ancient monument is in danger of destruction, removal, or damage from neglect or injudicious treatment. Acting on advice from the Ancient Monuments Board, he may serve an interim preservation notice on the owners. Procedures are available for compensating owners who may claim injury while the notice is in force. ${ }^{5}$

In I966, listed buildings were subject to the relevant provisions of the Town and Country Planning Act $\mathbf{I} 962 .{ }^{6}$ By this legislation the Minister is required to compile lists of buildings of special architectural or historic interest. By mid-rg66, over 90,000 buildings in England and Wales had been placed on the statutory lists. A provisional list of buildings was first prepared. It divided buildings into four categories:

Grade I Buildings of outstanding interest. (Only about four per cent of statutory buildings are in this grade.)

Grade II* Buildings of special interest which warrant every effort to preserve Grade II them. (Most such buildings are classified as Grade II; particularly important ones in this grade are classified Grade II*)

Grade III Buildings which did not qualify for the statutory list by the standards current when the list was compiled, but which were important enough to be drawn to the attention of local authorities and others so that the case for preserving them could be fully considered.

These lists contain a brief description of the buildings. After local authorities were consulted concerning matters other than the merits of a building, buildings graded I, II*, and II are placed on the statutory lists; these contain neither grading nor description. In $x 966$, buildings graded III were included in separate lists known as supplementary lists which accompanied the statutory lists. Crown property could not be listed in I966. Churches could be listed although they were not subject to control while in ecclesiastical use. Churches of the Church of England were graded $A, B$, or $C$ on the provisional list, but these gradings were not be equated with the Grades I, II, and III used for other buildings. All such churches qualified for inclusion in the statutory list. Churches and chapels of other denominations were graded in the same way as secular buildings. ${ }^{7}$

Anyone seeking to demolish a building on the statutory list or to alter it in a way that would seriously affect its character was required to give two months' written

\footnotetext{
"Ancient Monuments Act I93I, 21 \& 22 Geo. 5, c. I6, § I5(I).

${ }^{5}$ Ancient Monuments Consolidation and Amendment Act I9ェ3, $3 \& 4$ Geo. 5, c. 32, $\$ \$ 3,4(2), 9$, II; Historic Buildings and Ancient Monuments Act 1953, I \& 2 Eliz. 2, c. 49, $\$ 5$, 7, I0, I2.

io \& II Eliz. 2, c. 38, $\$$ 30-33.

TId. $\$ \$ 30,32,199(2)(\mathrm{b})$.
} 
notice to the local planning authority, which in turn had to notify the Minister. It was then open to the local planning authority or the district council to issue a building preservation order. The effect of such an order, which had to be confirmed by the Minister, was to prohibit the demolition or serious alteration of the building without the express permission of the authority which made the order. The Minister could issue a building preservation order even though the local authority did not choose to do so. If a local planning authority were the owner of a listed building, notice of intended works had to be given to the Minister, who was empowered to issue a building preservation order. Any building of special interest, whether or not on the statutory list, could be made the subject of a building preservation order. The local authority had power to acquire a building for which a building preservation order was in effect if it were being improperly maintained. ${ }^{8}$

This procedure saved many worthy buildings that would otherwise have been destroyed, but it was limited to the preservation of individual buildings rather than areas as a whole, and it was extremely cumbrous. If neither the local planning authority nor the Minister acted within the rather short period of two months, the building could be destroyed or irretrievably altered. The situation in 1966 could not be regarded as satisfactory. If the owner of a listed building were not prevented from demolishing it within two months, he could proceed with his plans, even if he knew the local authority and the Minister were considering issuing a building preservation order.

Two months was an unrealistic period within which to issue a building preservation order. Many fine buildings were lost before an order could be confirmed. Because the emphasis in preservation was so strongly placed on the individual building, rather than on groups of buildings and buildings in their settings, historic areas in many towns were gradually eroded. Some historic towns were developed in such a way that their historic characters and their appearances were very much degraded. Such developments were largely the result of defects in the system, but they were also encouraged because public opinion had not been alerted to the value of its architectural and historic heritage and no attention was given to the fact that historic buildings were disappearing at the rate of about 400 a year.

\section{II}

\section{Legislation Since ig66 and the Present Situation}

It has already been noted that a radical change in both law and attitude has occurred since 1966 . The statutory situation has changed as a result of the passage by Parliament of several acts. ${ }^{9}$ The best way to conceptualize the present situation is to subdivide the subject into three broad headings:

\footnotetext{
${ }^{8} I d . \$ \$ 30,32,69,207$.

${ }^{9}$ Civic Amenities Act 1967 , c. 69; Town and Country Planning Act 1968, c. 72; Countryside Act 1968, c. 4I; Transport Act 1968 , c. 73; Housing Act 1969, c. 33. This demonstrates that in Britain the legal provisions for protecting our inheritance are contained in a number of different acts.
} 
A. Individual Buildings.

B. Groups of buildings within a town, city, or village. (This could conceivably encompass an entire village.)

C. The conservation of entire tracts of countryside including villages and small towns within them.

\section{A. Individual Buildings}

The Civic Amenities Act Ig67 strengthened the existing legislation with respect to listed buildings. Six months notice instead of two now must be given for proposals to alter or demolish a listed building. Penalties were introduced for unauthorized works on listed buildings and acts likely to damage them. Power to acquire a neglected listed building were extended to cover all listed buildings, and local authorities were given the power to issue to owners a repairs notice with respect to listed buildings urgently in need of repair. If the notice is not complied with in seven days, the local authorities may carry out the repairs. ${ }^{10}$

The Town and Country Planning Act I 968 has done much more. Part V has replaced the cumbersome system of building preservation orders with a system of listed building consents, which works in much the same way as the system of planning permission for new development. Listed building consent is needed prior to alteration or demolition of a listed building, and all applications must be advertised. National amenity societies must be notified of applications for consent to demolish listed buildings, and local authorities have been asked to notify local amenity and civic societies as well. These arrangements and requirements with respect to advertisement in the press provide a means whereby the public can receive information and can express its views. In the same manner as applications for new development, the Minister may require applications to be submitted to him, and he must determine appeals from the refusal of listed building consent, and from enforcement notices. He must also hear proposals for the modification and revocation of listed building consents. The owner of a listed building has no right to challenge the listing of his building, but he has a right to challenge all the consequences of that listing. 11

Part V contains other important provisions for safeguarding listed buildings. If alteration or demolition threatens an unlisted building regarded by the local planning authority as worthy of listing, the local authority may serve a building preservation notice which, for a maximum period of six months, gives the building the same protection as a listed building. The Minister then has six months to decide whether to list it. The local planning authority may not only issue a compulsory purchase order with respect to a neglected historic building, but if it considers the neglect to have been deliberate, it may apply for a certificate of minimum compensation. This enables the local authorities to acquire the building at a price which ignores the development

\footnotetext{
${ }^{10}$ Civic Amenities Act 1967, c. $69, \S \S 2,7,6$.

${ }^{11}$ Town and Country Planning Act 1968, c. 72, $\$ 40$, sched. 5 .
} 
value of the site. A person working on a listed building without the necessary authority is subject to a heavy fine and imprisonment. Also, he may be required to restore the building to its former state. If he refuses to comply with the ordered restoration, a heavy fine may be imposed, with a further fine for each day the requirement remains unfulfilled. The existence of these provisions should deter people from deliberately neglecting their old buildings in order to realize their site value and from carrying out unauthorized alterations and demolitions. When the minister is considering whether to list a building which is part of a group, he has an important new power to take into account the extent to which a building's exterior contributes to the architectural or historic interest of the group. The Act also provides that Crown property can be listed and, although Crown development is not subject to statutory control, development by Crown lessees is subject to listed building control. ${ }^{12}$

\section{B. Groups of Buildings}

Probably the most important provision of the Civic Amenities Act 1967 was the duty it placed on local planning authorities to identify those parts of their areas which are of special architectural or historic interest and to designate them as conservation areas. They must pay special attention to the desirability of preserving or enhancing the character of such an area when exercising their planning functions. They must also advertise applications for development which would affect the character or appearance of a conservation area. The great importance of these provisions is that they give the first statutory recognition to the fact that entire areas have a character that is more than the individual characteristics of the separate buildings, and that groups of buildings may have special merit even when no individual building is listed. ${ }^{13}$

In Britain much of the force of a piece of legislation may be in the regulations a Minister issues or the advice he gives in a circular. In the case of the Civic Amenities Act, a number of guidelines were contained in a circular and its accompanying memorandum. In that circular the attention of local authorities was drawn to the new powers available to it.

[T] he Ministers will welcome the co-operation of local authorities in taking firmer action to protect buildings of special architectural or historic interest. ...

... The great majority of listed buildings are still capable of beneficial use in the present day, and given skill and understanding new development can usually be made to blend happily with the old. The destruction of listed buildings is very seldom necessary for the sake of improvement; more often it is the result of neglect, or of failure to appreciate good architecture.

Designation of a conservation area will be only preliminary to action to preserve or enhance its character and appearance: it will be of little practical value without this. The local planning authority, with the agreement of the local authority

\footnotetext{
${ }^{12} I d . \$ \$ 44,45,48,50,53,54,60$.

${ }^{13}$ Civic Amenities Act I967, c. $69, \S I$.
} 
where appropriate, should therefore adopt a positive scheme of action for each area at an early stage.

...

The first need will be to decide how far new development should or should not be permitted in the conservation area. . . . It will be important to see that every new building is designed not as a separate entity, but as part of the larger whole--as a new-comer to a scene with a well established character of its own. ...

Proposals for new development that are likely to affect the character of a conservation area to any significant extent may be of general public concern. Section I(6) of the Act recognises this by requiring planning authorities to advertise such applications, indicating the nature of the development in question, and to consider any representations they may receive in deciding whether or not to grant permission. Authorities are asked to make full use of this procedure, and it is hoped that they will find it helpful in reaching the right decisions on the more important proposals affecting conservation areas. . . .

Anything that can be done to raise the environmental quality of an area following its designation as a conservation area may stimulate efforts to preserve the good buildings in the area, and local authorities may be able to help more directly by paying grants for repairs or by taking the lead in restoring particular buildings themselves. ... .14

The Town and Country Planning Act I968 also has provisions concerning conservation areas. It empowers the Minister to direct local planning authorities to consult specified persons or organizations with regard to planning applications for development in conservation areas and with regard to applications for listed building consent. ${ }^{15}$ He has issued directions concerning the latter but not the former. Instead he has urged local authorities to set up conservation area committees.

The Minister suggests that local planning authorities should establish conservation area advisory committees, including persons not members of the authority, and refer to them for advice on applications which would, in the opinion of the authority, affect the character or appearance of the conservation area. It would be for the authority to decide whether to set up one committee (which might be the right solution for e.g. a county borough or London borough with very few conservation areas) or several committees (which would be appropriate for a county with scattered conservation areas or a borough with a considerable number of them). The Minister suggests that nominations to serve on such committees should be sought from the Royal Institute of British Architects, the Town Planning Institute and any other national bodies which the authority think appropriate; and from county or other local archaeological, historical and civic and amenity societies. Where a conservation area is in a residential neighbourhood, consideration should be given to inviting a resident or residents to serve on the advisory committee. Where a conservation area contains a shopping and commercial centre, it may be appropriate to invite representatives of the

\footnotetext{
14 Ministry of Housing and Local Gov't, Crvic Amenities Act I967-Parts I \& II, Circular $53 / 67$, at 3,9 , ro (Aug. 7,1967 ).

${ }^{25}$ Town and Country Planning Act I968, c. 72, 556 .
} 
local Chamber of Trade or Street Association to serve. The Civic Trust, the Council for British Archaeology, and Councils for Rural Preservation and building preservation bodies at national level can be consulted about the local civic and amenity, historical or archaeological societies to be approached for nominations. The work of these advisory committees need not be confined to questions arising on applications for planning permission or listed building consent. They could also play a useful part in the general care and maintenance of conservation areas and in making positive proposals for their enhancement. ${ }^{18}$

Part VI of the Act provides that a local planning authority may apply to the Minister of Transport for an order converting an existing road to a footpath as part of a proposal to improve the amenity of part of its area. Such an order would extinguish the right to use a vehicle on the road and would create a permanent pedestrian way. ${ }^{17}$ Part IX of the Transport Act I968 is related to this in that it empowers the local authority to deny the use of a road to vehicles on amenity grounds for periods not exceeding eight hours a day. With the Minister's approval the prohibited period may be made longer. ${ }^{18}$ The Housing Act Ig69 also allows a local authority to close roads to traffic within General Improvement Areas. ${ }^{10}$

Finally, the Housing Act 1969 has measures which affect individual buildings and groups in conservation areas in what is one of the vexed aspects of conservation, finance. For some time successive governments have been anxious to secure improvement to old houses deficient in amenities but still sound structurally. The 1969 Housing Act provided new powers and incentives to owners and local authorities. The formal discretionary grant rose from $\$ 960$ to $\$ 2,400$, and the conversion grant rose from $\$ \mathrm{r}$, I00 per flat obtained by conversion to $\$ 3,28 \mathrm{o}$. Of particular interest is the concept of general improvement areas within which the local authority can improve not only individual houses but also the surrounding environment. In addition to the grants payable for the improvement of the property, local authorities can qualify for a grant of half the cost of carrying out environmental improvements in a general improvement area, subject to an expenditure limit of $\$ 240$ per dwelling in the area. This is particularly relevant to buildings of special architectural or historic interest. In a case in which conversion of these properties so that the new work blends harmoniously with the old is so expensive that it cannot be assisted within the normal limits, the Minister may consider higher grants. ${ }^{20}$

\section{The Wider Conservation of Whole Tracts of Countryside}

Because the United States has such extensive national parks, perhaps the meaning of certain terms in Britain should be clarified.

A national park is an extensive tract of country which should be preserved or

\footnotetext{
${ }^{16}$ Mintstry of Housing and Locax Gov't, Town and Country Planning Act-Part V, Circular $6 \mathrm{r} / 68$, at 8 (Dec. $4, \mathrm{Ig} 68$ ).

17 Town and Country Planning Act 1968, c. 72, 92 .

${ }^{18}$ Transport Act 1968, c. $73, \S \pm 26$.

${ }^{10}$ Housing Act 1969, c. 33, $\$ 33$.

${ }^{20} I d . \$ \$ 5,28,37$.
} 
enhanced because of its natural beauty and the chances it offers for open-air recreation. Designation as a national park does not entail a change in ownership nor does it guarantee access to the general public. It has been said they are neither national nor parks. The Minister or a local authority may acquire parts of a park if it deems it necessary in order to preserve or enhance it. And the local authority can, by agreement or by an order confirmed by the Minister, obtain public access to the area. The local authority has power to provide accommodations and facilities. ${ }^{21}$

The term area of outstanding natural beauty is self-explanatory. Designation procedure is similar to that for national parks. The differences are that the tract of country need not be "extensive" nor need it provide opportunities for openair recreation, and the local authority managing the area has no power to provide accommodations or camping facilities. One of the principal practical effects of designation is that grants for acquisition are made available. ${ }^{22}$

Conservation of especially beautiful countryside is considered in the various acts concerned with national parks and public access to the countryside. ${ }^{23}$ Most of these were enacted before 1966 , but the Countryside Act of Ig68 added to the powers granted in the other acts. It enabled local authorities to acquire land for country parks. These were designed to be tracts of land especially developed as recreational centers for urban dwellers. Parliament's intention was to reduce pressure on the national parks and areas of outstanding natural beauty by providing alternative "pleasure centers."24

Perhaps the most important factor in securing conservation of the countryside is the existence of the Countryside Commission which is directly charged with preserving and enhancing natural beauty, giving advice about natural beauty, and encouraging facilities for the enjoyment of the countryside. ${ }^{25}$

\section{Recommendations}

There are gaps in the present statutes. The Preservation Policy Group itself drew attention to two of them and suggested ways of closing them.

First, although local authorities have the power under Section 6 of the Civic Amenities Act I 967 to carry out works which are urgently necessary for the preservation of an unoccupied listed building they must do so at their own expense: they have no power to recover the cost from the owner even if the building has been wilfully neglected for financial gain. This is hardly an incentive to local authorities to take speedy action, or to owners to keep their buildings in repair themselves.

We have considered sections 36 and 59 of the Town and Country Planning Act 1962 which enable local planning authorities to serve notice on the owner of

\footnotetext{
${ }^{21}$ National Parks and Access to the Countryside Act 1949, 12, 13, \& I4, Geo. 6, c. 97, §§ 5, I2, I4, 64.

${ }^{22} 7 d . \$ 87$.

${ }^{23}$ National Parks and Access to the Countryside Act I949, I2, I3 \& I4 Geo. 6, c. 97. Forestry Acts I919, 1923, 1927, 1945, 1947, and I95I were consolidated by Forestry Act I967, c. I0.

2थ Countryside Act I968, c. 4I $\$ \S 6-7$.

${ }^{35} I d$. $\S$.
} 
a garden or vacant land that is injuring amenity, requiring him to abate the injury: if this notice is not complied with in a specified time (at least 28 days) the local planning authority can themselves do the work and recover the cost. There is a right of appeal against such a notice to a magistrate's court. We recommend that analogous provision should be made for emergency repairs to listed buildings, so that local authorities can recover the cost of repairs they have carried out under Section 6 of the Civic Amenities Act 196\%. This seems reasonable because the repairs carried out by the authority will have preserved the value of the property to the owner. A relatively small amount spent on emergency repairs can often prevent deterioration which will cost far more to remedy.

We think, therefore, that Section 6 of the Civic Amenities Act should be examined and, if necessary, amended, to ensure that it covers works necessary to keep a building weatherproof so far as may be reasonably possible, to prevent danger to persons in or adjoining the building and to prevent further deterioration. There should be provision for serving a notice on the owner, if he can be traced, describing the works to be done and giving him a period in which to appeal to a magistrate's court if he considers the works unnecessary or outside the terms of the section. The council should be able to recover the cost of emergency work done under these powers but, again, there should be a right of appeal to a magistrate's court against the amount to be recovered.

The second gap which we think exists in the present legislation relates to buildings that have a considerable "break-up" value, i.e., where detachable things such as panelling, staircases and fireplaces would fetch a considerable sum in the saleroom if the building were demolished. An owner who has deliberately neglected his listed building in order to realise the development value of the site can be deprived of that value if the building is acquired by the local authority in order to preserve it. But if an owner is refused listed building consent to demolish a building and subsequently serves a purchase notice on the local authority, and this notice is accepted or confirmed (or if a building is acquired compulsorily because it is neglected) the price the local authority pay may well under existing law include a break-up value.

We are agreed that, where a building has been deliberately neglected to enable the owner to realise its break-up value, he should not be allowed to profit by his neglect, and we think Section 53 of the Town and Country Planning Act I968 should be amended to deal with break-up value as well as development value. ${ }^{20}$

A further loophole in the law is that once local authorities have designated conservation areas, they are under no compulsion to do anything further. This brings us to the next stage.

III

\section{The Will to Conserve}

Much of the will to conserve has been expressed through individuals, either members of voluntary bodies or semi-official advisory boards or councils. Some of these bodies should be listed.

\footnotetext{
${ }^{20}$ Preservation Policy Grotp, supra note 2, at $17-\mathrm{I} 8$.
} 
(I) The Society for the Protection of Ancient Buildings is a voluntary body, founded by William Morris in 1877 to prevent the worst ravages of Victorian restoration.

(2) The Historic Buildings Council is an official body advising the Minister on buildings or groups of buildings of outstanding architectural or historic interest. It advises on the presentation of grants for repair. ${ }^{27}$

(3) The National Trust, established by Act of Parliament in 1907, receives income from Parliament and voluntary contributions. It is empowered to acquire buildings or countryside for conservation in the name of the general public. It can receive buildings as gifts, endowments, or in lieu of death taxes. ${ }^{28}$

(4) The Georgian and Victorian Societies are voluntary bodies dedicated to the love and preservation of buildings and artifacts dating from those periods.

(5) The Council for the Protection of Rural England is an entirely voluntary body the purposes of which are self-explanatory.

(6) The Civic Trust and its regional counterparts, which are autonomous and financially separate, are dedicated to promoting higher standards of planning and architecture. It is not just a preservationist body; it is much concerned with design in new buildings. Registered with the Trust are over 700 local amenity societies representing a very large number of individuals.

All of these bodies express the growing concern with conservation in Britain. Membership of all is increasing, and their presence and voice at public inquiries is becoming more and more apparent. It is probably only this voice that will make it possible for new steps to be taken within government to provide resources in skill and finance.

\section{A. Technical Advice}

Bodies such as the Civic Trust with full time qualified staffs are able to render advice, and the Trust has in the past few years provided a substantial body of documents on various aspects of conservation and enhancement. These are listed in the appendix. But the Preservation Policy Group was correct when it acknowledged the need for the Department of the Environment to prepare a series of memoranda. They suggested that the following subjects might be covered.

a) The siting and design of street furniture with particular reference to traffic signs and street lighting. It is as needful to regulate the traffic in a historic town as it is in any other, and it can be done without a forest of large and unsightly signs if unduly complex Traffic Regulation Orders are avoided.

b) Multi-storey car parks. Obviously, if historic towns are to cater for visitors, car parks must be provided and it would be rash to lay down that multi-storey car parks should never be allowed in historic towns. Nevertheless the siting and

\footnotetext{
${ }^{27}$ Historic Buildings and Ancient Monuments Act I953, I \& 2 Eliz. 2, c. 49, $\S$ I-4. At the present the grants total about $\$$ I.3 million per year.

${ }^{28}$ National Trust Act 1907,7 Edw. 7, c. 136.
} 
design of car parks for historic towns need great care, both in relation to the impact the actual structure will have on surrounding buildings and to the effect that cars coming in and out will have on other traffic and on pedestrians.

c) The re-use of old materials. It is sometimes necessary for fine old buildings to be pulled down, and where this is done as much as possible of the materials should be stored, and local authorities should be given advice on how to store them safely and how to re-use them.

d) The General Development Order 1963 gives a general planning permission to carry out various minor developments, such as the building of small extensions, repainting and fencing (although if the building is listed specific listed building consent may still be needed). The Minister can approve an Article 4 direction made by a local planning authority that, in a particular area, specific planning permission is needed for minor works such as these. This is a useful tool for ensuring the seemly appearance of a conservation area or a historic centre, and we recommend that guidance on its use should be issued, especially in conservation areas.

e) Estate management techniques covering land tenure, the use of covenants and the integration of both planning and estate control to ensure repair, conversion, redevelopment and improvements to the environment, must contribute to a planned programme of conservation. Some local authorties such as Bath Corporation, already own much property in their historic towns, and in these cases the cost of the conversion itself may be one of the principal problems to be overcome. Sound estate management is as important for conservation areas as it is for redevelopment schemes, and we think local authorities would welcome advice on this point. ${ }^{29}$

\section{B. Finance}

Finance, of course, is the heart of the matter. Whatever the technical difficulties of conservation and enhancement are, they are ultimately soluble, but only at some cost. The money being provided by government, centrally or locally, is at present inadequate. It is available in several ways. (i) The Minister can present grants for the repair of buildings of outstanding interest. ${ }^{30}$ (ii) $\mathrm{He}$ can make loans to people who own buildings which are special but not oustanding. However, there is no loan fund and the Minister has never made a loan. (iii) Local authorities can make loans or grants. This has not been often done. The figure for I968-69 was $\$ 480,000$, but this figure includes the local authorities' shares in "town schemes" for which half the money is provided by the Minister on the advice of the Historic Buildings Council. (iv) The government can provide grants under the Housing Act $1969 .^{81}$ (v) The National Trust can acquire property for preservation purposes. (vi) The Minister can acquire, repair, and sell property. The rest of the cost of conservation has to be met privately and is being met to a large degree. But more pressure will have to be placed on government, or we will find conservation falling behind development.

\footnotetext{
${ }^{29}$ Preservation Pozicy Group, stupra note 2, at 23.

${ }^{80}$ Historic Buildings and Ancient Monuments Act $\mathrm{r953}$, I \& 2 Eliz. 2, c. $49, \S 4$. See note 27 stipra.

${ }^{32}$ See text accompanying note 20 stupra.
} 
Again the Preservation Policy Group has listed a number of steps which might be taken.

I. Legislation should be introduced to enable local authorties who submit a new type of General Conservation Scheme to be paid exchequer grant to meet fifty per cent of the deficiency on their operation.

2. Pilot schemes of this nature should be carried out immediately in advance of legislation, in Bath, Chester, Chichester and York.

3. The annual grants and loans to the owners of outstanding historic houses made by the Minister of Housing and Local Government on the advice of the Historic Buildings Council should be increased substantially beyond the present figure [\$r.3 million] to enable both more individual houses to be assisted and more town schemes to be undertaken.

4. The possibility of an exchequer subsidy towards local authority expenditure on the repair of listed buildings not included in Town Schemes or General Conservation Schemes should be considered.

5. The possibility of introducing legislation so that the Government may guarantee advances made by building societies on the security of historic buildings should be considered.

6. Local planning authorities should be given power to charge the owner when they themselves repair listed buildings.

7. Existing legislation should be amended so that if an owner deliberately neglects a listed building in order to realise its break-up value the local authority may acquire the building at a price which excludes the break-up value element. ${ }^{32}$

\section{Conclusion}

In this paper no mention has been made of enhancement measures that are taking place in Britain. Trees are being planted at an increased rate; properties are being cleaned of $15^{\circ}$ years of grime; non-conforming uses are gradually being removed from historic towns and town centers; foot streets have been created in Norwich, Bolton, and York. Several things point to the need for constant vigilance.

Most of the recommendations of the Preservation Policy Group, for example, are still recommendations. Also, the government has refused to increase the amount of money being allocated by the Minister. There is to be no money for the pilot studies at York, Bath, Chester, or Chichester.

Moreover, there has been clear evidence during the past year that proposals apparently unconnected with conservation could substantially affect historic buildings or conservation areas. Late in 1969 the motor manufacturers sought to increase the maximum permitted weight and size of commercial vehicles. The Ministry of Transport consulted a number of bodies, including the Civic Trust, to establish their reaction. The Trust consulted over 700 local amenity societies and in a very short time received over $3^{00}$ replies. These were assembled and assessed in the Trust's report on heavy lorries. The report provided some basic information upon which the proposal could be assessed and also indicated the immense amount of

\footnotetext{
${ }^{33}$ Preservation Policy Group, supra note 2 , at $3 \mathrm{r}$.
} 
damage being done by existing heavy lorries. ${ }^{33}$ The Secretary of State for the Environment rejected the proposed increase late last year, but the motor manufacturers will no doubt raise the question again. Finally, within the last year insufficient Parliamentary time has been given to a Private Members Bill which attempts to close some of the gaps in existing legislation on protecting the environment in conservation areas. Consequently, it is not now likely to become law.

We still need, in William Morris' words, to awaken and keep awake "the feeling that our ancient buildings are not mere toys but sacred monuments of the nation's growth and hope."

\section{Appendix}

Documents on various aspects of conservation and enhancement by the national Civic Trust and the Civic Trust for the North West (CTNW).

\section{The following are publications of the Civic Trust, Carlton House Terrace, Lon- don.}

Conservation and the Role of the Local Society. This is a paper read by Michael Middleton, Director of the Civic Trust. This paper suggests the part that the local amenity society may be able to play in the implementation of conservation area policies. (out of print)

York Conference of Amentty Societies: Report of Proceedings and Background Papers. In September 1968 a national conference of amenity societies was organized by the Civic Trust at the University of York. This report includes papers on Functions and Organizations, The Planning Process, Traffic and Environment, Conservation, and New Development. (out of print)

Civic Trust Awards. Each year the Trust makes Awards for modern buildings of distinction the designs of which pay due regard to their surroundings, and for developments of all types which improve the scene.

Magdalen Street, Norwich $(1967)$. The street improvement scheme undertaken by the Trust in Norwich was the model for many other similar projects. It demonstrates how a worn shopping strect could be rehabilitated by means of a co-ordinated redecoration scheme and the removal of superfluous clutter.

Street Improvenent Schenas. A buoklet, intended mainly for local authorities, local societies and traders' associations, describing in detail how to promote a street improvement scheme.

ShOP FroNT (1963). An illustrated booklet demonstrates how well-designed shopfronts enhance their surroundings.

The Crvic Trust Trees Carpaign. A booklet outlining the origin and development of the Trust's Plant More Trees campaign which was launched in 1966.

Trie Preservation and Peanting of Trees (I967). In the context of the Civic Amenities Act I967, this document suggests how acceptable standards might be devised for the planting of trees on new developments.

The Trust in Planning ( 1967 ). A planning guide for rebuilding city centers, urban renewal, housing regeneration, conservation areas, reclaiming derelict land, and planning for leisure.

Conservation Areas ( $(967)$. An illustrated Civic Trust survey deals with the opportunitics for area and group preservation offered by the provisions of the Civic Amenities Act.

Protection of Areas of Architectural Importance ( 1967 ). This booklet looks at the wide range of areas considered by fifteen local authorities to be eligible for designation as Conservation Areas under section I of the Civic Amenities Act 1967.

DeRelict LAND ( 1964 ). An illustrated survey of land rendered derelict by all types of mincral extraction suggests methods of rehabilitation.

Tourism aND CONSERvation IN CONWAy (I969). An illustrated study suggesting the way in which a developing tourist and vacation trade might contribute in practical terms to the conservation of an important historic town.

\footnotetext{
ss The Crvic Trost, Heavy Lorrues (I970).
} 
HeAvy LoRries (I970). A survey and analysis of the effect of heavy lorries on the environment.

Trie Effect of Public Utirity Works upoN the ENvironment (1966). A paper by Graham Ashworth presented to the Annual Conference of the Royal Institute of British Architects in Dublin.

\section{The following are publications of the Civic Trust for the North West, 56 Oxford Street, Manchester, England.}

Area Rejuvenation (I965). A pilot study for the rehabilitation of an area of substandard housing in Rochdale.

Stone-Its Future Appearance (I966). Guidance for the control of the built environment of Stone, Staffordshire. Reprint of an article from the Town Planning Review by Graham Ashworth.

CAR PaRks (rg68). Detailed suggestions for the design and layout of surface car parks.

Cheshire Villages: An Environmental Vocabulary (I969). Cheshire villages have been placed into three categories by the county Council. This report suggests how new development could be integrated into each category of village without detriment to existing character and identity.

Environmental Recovery at Skemmersdale (1969). Description of the aims and management of an Environmental Recovery Project at Skelmersdale between 1966 and 1969 under the aegis of CTNW and the University of Manchester Institute of Science and Technology. The scheme anticipated one of the principal objectives of the Housing Act 1969 .

Haworth: TourISM AND CONSERvation (I97r). Recommendations for expanding the tourist industry and conserving the character of the Bronte village of Haworth, Yorkshire.

RAMsbottom: STUDY OF A VALIEY Town (Ig7I). Guidance for the control, maintenance and improvement of the environment of Ramsbottom, Lancashire. 